TAO, Vol. 17, No. 1, 277-294, March 2006

\title{
Changes in $\mathrm{NO}_{2}$ Concentration from Major Cities and Provinces in Korea: A Case Study from 1998 to 2003
}

\author{
Hang Thi Nguyen ${ }^{1}$, and Ki-Hyun Kim ${ }^{1}{ }^{1 *}$ \\ (Manuscript received 27 July 2005, in final form 20 December 2005)
}

\begin{abstract}
In this paper, the spatio-temporal distribution characteristics of nitrogen dioxide $\left(\mathrm{NO}_{2}\right)$ were investigated using data obtained routinely from air quality monitoring stations located in seven major cities and nine provinces in Korea for the period 1998 to 2003. The results indicate that annual trends in $\mathrm{NO}_{2}$ concentrations generally reflect changes in environmental conditions, while exhibiting cyclic and systematic patterns across seasons. Its wintertime concentrations were most prominent, with concentrations decreasing gradually across spring, fall, and summer. If concentration patterns are examined among different cities and/or provinces, the highest mean values were found from the Capital city, Seoul ( $34.7 \mathrm{ppb})$ and the surrounding province, Gyunggi (30.2 ppb). In contrast, remarkably reduced $\mathrm{NO}_{2}$ concentrations were seen in such regions as the remote island, Jeju and Jeonnam province with mean values of 17.5 and $16.5 \mathrm{ppb}$, respectively. The overall results of our study indicate that there are strong geographical gradients in $\mathrm{NO}_{2}$ distributions to exhibit strongly polluted patterns consistently in densely populated urban areas (e.g., major city), compared to large rural areas (e.g., province).
\end{abstract}

(Key words: Nitrogen dioxide, Pollution, Spatial, Temporal, Korea)

\section{INTRODUCTION}

A broad spectrum of pollutants, which include sulfur and nitrogen oxides, are released into the atmospheric environment as a result of both natural and man-made activities. Pollutant emissions adversely impact air quality and consequently human health. Policymakers and

\footnotetext{
1 Department of Earth \& Environmental Sciences, Sejong University, Seoul, Korea

* Corresponding author address: Prof. Ki-Hyun Kim, Department of Earth \& Environmental Sciences, Sejong University, Seoul, Korea; E-mail: khkim@sejong.ac.kr
} 
scientists thus pay a great deal of attention to the various health effects of air pollution, such as those which occur due to chronic exposure to ambient air pollution; for example, epidemiological studies have pointed out specific concerns about traffic pollution. Here accounts of notable health effects such as cardiopulmonary mortality among those residing near major road areas have been reported (e.g., Hoek et al. 2002).

In environments affected by high traffic loadings, pollutant emission patterns need to be described precisely as direct emissions of airborne pollutants such as nitrogen oxides can have a large effect on the total pollution budget (Stedman et al. 2001). Concentrations of $\mathrm{NO}_{2}$ and other vehicular pollutants in the atmospheric environment have increased substantially with vehicular populations. However, vehicular populations alone do not govern the overall extent of such pollution; for example, $\mathrm{NO}_{2}$ concentrations have been shown to be affected by a number of parameters including vehicle type, fuel used, and vehicle operating conditions (Carslaw et al. 2005). Maximum $\mathrm{NO}_{2}$ emissions in Korea are seen mainly in big cities and over industrial areas, where $\mathrm{NO}_{2}$ emissions have been found to exceed 10,000 equivalents (eq) $\mathrm{ha}^{-1} \mathrm{yr}^{-1}$ (Park and Lee 2002).

$\mathrm{NO}_{2}$ is released into the atmosphere directly as a product of combustion processes (Silibello et al. 1998) or as a result of conversion through oxidation of $\mathrm{NO}$ by ozone $\left(\mathrm{O}_{3}\right)$ or oxygen $\left(\mathrm{O}_{2}\right)$ (Mackenzie et al. 1995; Soltic and Weilenmann 2003). Problems caused by air pollution due to such photochemical oxidants have been recorded in many of previous studies (e.g., Lee et al. 1996). The environmental fate of ozone $\left(\mathrm{O}_{3}\right)$ and nitrogen dioxide $\left(\mathrm{NO}_{2}\right)$ are important, due to their potential to adversely impact surrounding ecological systems. Because of their chemical coupling, the concentration levels of $\mathrm{O}_{3}$ and $\mathrm{NO}_{2}$ are often inextricably linked to each other (Mazzeo et al. 2005). Hence, a better knowledge of these chemicals is a prerequisite to providing more efficient methods for their control. In this study, we investigate $\mathrm{NO}_{2}$ measurement data collected from seven major cities and nine provinces in Korea during the period 1998 to 2003. In order to provide a better description of $\mathrm{NO}_{2}$ behavior, those $\mathrm{NO}_{2}$ data were examined on the basis of diverse temporal and spatial criteria. To explain factors affecting the distribution of $\mathrm{NO}_{2}$ across different cities or provinces, correlation analysis was also conducted.

\section{MATERIALS AND METHODS}

Concentrations of $\mathrm{NO}_{2}$ were determined from air quality monitoring stations dispersed across a total of 16 districts (seven major cities and nine provinces) in Korea from 1998 to 2003 (Fig. 1). To estimate $\mathrm{NO}_{2}$ pollution levels in each district, concentration levels of criteria pollutants reported by the Korean Ministry of the Environment (KMOE) were used(Table 1). The original concentration data were quality-controlled and stored in a data management network system operated by the KMOE (refer to regulation criteria in Table 1). The initial datasets recorded routinely at hourly intervals from each monitoring station were stored in the KMOE data management system after being converted into monthly intervals. The QA/QC for these data have been reported in the KMOE annual reports.

The number of individual air quality monitoring (AQM) stations in Korea increased gradually each year throughout the study period, i.e., from 127 (1998) to 190 (2003), as shown 


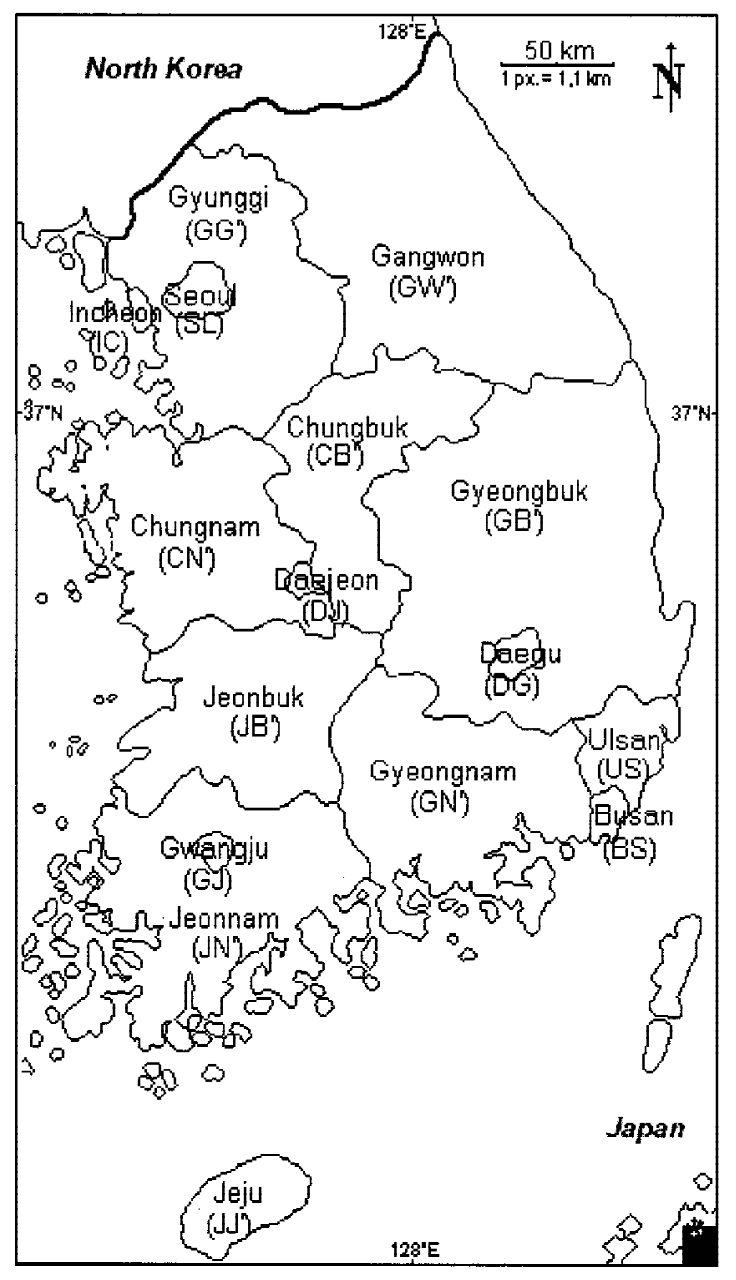

Fig. 1. A map of S. Korea is drawn to show all districts for air quality monitoring in Korea. Short name of each district are given in the parenthesis. For all provinces, "' symbols are also added next to the two letters to make easy comparison with the short names of major cities.

in Table 2. For the purpose of classification, all of the $\mathrm{NO}_{2}$ data collected from those individual stations were grouped into the 16 major administrative districts. The geographical locations of these major cities and provinces in Korea are described in Fig.1. After being grouped, the $\mathrm{NO}_{2}$ datasets for all individual stations were combined together to derive values for each respective district. Due to this combining process, each of these 16 districts has a total of 72 monthly $\mathrm{NO}_{2}$ concentration values to represent its distribution patterns for the entire study period. In the course of this study, $\mathrm{NO}_{2}$ values converted by the above procedure were exam- 
Table 1 . The types of criteria pollutants regulated by the Korea Ministry of the Environment (KMOE). (Exceedance criteria set in 1995 are given along with each respective measurement method).

\begin{tabular}{lll}
\hline & \multicolumn{1}{c}{ Standard } & Experimental Method \\
\hline $\mathrm{SO}_{2}$ & - yearly average $<0.02 \mathrm{ppm}$ & Pulse U.V.flourescence \\
& - 24-hour average $<0.05 \mathrm{ppm}$ & \\
& - 1-hour average $<0.15 \mathrm{ppm}$ & \\
$\mathrm{CO}$ & - 8 -hour average $<9 \mathrm{ppm}$ & Non-dispersive infared \\
& - 1-hour average $<25 \mathrm{ppm}$ & \\
$\mathrm{NO}_{2}$ & - yearly average $<0.05 \mathrm{ppm}$ & Chemiluminescent \\
& - 24-hour average $<0.08 \mathrm{ppm}$ & \\
& - 1-hour average $<0.15 \mathrm{ppm}$ & \\
$\mathrm{PM} 10$ & - yearly average $<70 \mu \mathrm{g} / \mathrm{m}^{3}$ & \\
& - 4-hour average $<150 \mu \mathrm{g} / \mathrm{m}^{3}$ & \\
$\mathrm{O}_{3}$ & - 8-hour average $<0.06 \mathrm{ppm}$ & U.V.photometric \\
& - 1-hour average $<0.1 \mathrm{ppm}$ & \\
$\mathrm{Pb}$ & - yearly average $<0.5 \mu \mathrm{g} / \mathrm{m}^{3}$ & Atomic absorption spectrophotometry \\
\hline
\end{tabular}

ined further at various temporal scales (e.g., seasonal and inter-annual trends) for each individual district. In addition, using monthly mean datasets for all different districts, correlation patterns were also analyzed and evaluated.

\section{RESULTS AND DISCUSSION}

\subsection{Spatial Distribution Patterns of $\mathrm{NO}_{2}$ Data}

The mean, min., and max. values for each specific month throughout the study period were computed for each individual district after pooling and combining monthly datasets from the sum of 127 to 190 individual stations; in the case of Seoul, the number of individual stations varied from 27 (1998 - 2002) to 31 (2003) (Table 2). In order to examine spatial factors on $\mathrm{NO}_{2}$ distribution patterns, basic statistical parameters derived from the above procedure were further evaluated for each district (Table 3). For the description of $\mathrm{NO}_{2}$ distribution patterns for each district, we use the short symbols presented in Table 2 (e.g., Seoul to SL) 
Table 2. The number of total individual stations for the comparison of $\mathrm{NO}_{2}$ distribution patterns on a district basis (seven major cites and nine provinces).

\begin{tabular}{|c|c|c|c|c|c|c|c|c|}
\hline \multicolumn{3}{|c|}{ City/Province } & \multirow[t]{2}{*}{1998} & \multirow[t]{2}{*}{1999} & \multirow[t]{2}{*}{2000} & \multirow[t]{2}{*}{2001} & \multirow[t]{2}{*}{2002} & \multirow[t]{2}{*}{2003} \\
\hline & Full name & Short name & & & & & & \\
\hline \multirow{7}{*}{$\begin{array}{l}\text { Seven } \\
\text { cities }\end{array}$} & Seoul & $\mathrm{SL}$ & 27 & 27 & 27 & 27 & 27 & 31 \\
\hline & Busan & BS & 9 & 9 & 9 & 9 & 13 & 16 \\
\hline & Daegu & DG & 6 & 7 & 6 & 6 & 7 & 11 \\
\hline & Incheon & IC & 8 & 10 & 10 & 10 & 10 & 11 \\
\hline & Gwangju & GJ & 4 & 4 & 4 & 4 & 4 & 4 \\
\hline & Daejeon & DJ & 3 & 3 & 3 & 3 & 3 & 5 \\
\hline & Ulsan & US & 7 & 7 & 11 & 12 & 12 & 14 \\
\hline \multirow{10}{*}{$\begin{array}{c}\text { Nine } \\
\text { provinces }\end{array}$} & Gyunggi & GG & 20 & 26 & 31 & 32 & 43 & 47 \\
\hline & Gangwon & GW & 4 & 4 & 4 & 5 & 4 & 8 \\
\hline & Chungbuk & $\mathrm{CB}$ & 4 & 4 & 4 & 4 & 4 & 5 \\
\hline & Chungnam & $\mathrm{CN}$ & 3 & 3 & 3 & 3 & 3 & 3 \\
\hline & Jeonbuk & JB & 6 & 6 & 6 & 6 & 6 & 6 \\
\hline & Jeonnam & $\mathrm{JN}$ & 8 & 8 & 8 & 8 & 8 & 9 \\
\hline & Gyeongbuk & GB & 9 & 9 & 9 & 10 & 10 & 10 \\
\hline & Gyeongnam & GN & 8 & 8 & 8 & 8 & 8 & 8 \\
\hline & Jeju & $\mathrm{JJ}$ & 1 & 1 & 1 & 1 & 2 & 2 \\
\hline & Sum & & 127 & 136 & 144 & 148 & 164 & 190 \\
\hline
\end{tabular}

throughout this text. As seen in Table 3, the highest mean of $\mathrm{NO}_{2}$ was found in SL (mean \pm $\mathrm{SD}: 34.7 \pm 6.38 \mathrm{ppb}, \mathrm{N}=72)$ followed by $\mathrm{GG}(30.2 \pm 5.88 \mathrm{ppb}, \mathrm{N}=72)$; GG province, while surrounding the capital city of SL, has a number of large industrial areas (including the Ansan industrial area). In contrast, the lowest mean $\mathrm{NO}_{2}$ level was seen in such provinces as JN $(16.5 \pm 3.43 \mathrm{ppb}, \mathrm{N}=72)$ and $\mathrm{JJ}$ province $(17.5 \pm 6.79 \mathrm{ppb}, \mathrm{N}=72)$. If the results of the two data groups (i.e., cities and provinces) are compared, moderate differences in $\mathrm{NO}_{2}$ concentration levels are indicated. The mean values for major cities increased in the following order: US, GJ, DJ, BS, IC, DG, and SL with values ranging from 19.6 to $34.7 \mathrm{ppb}$. The results for the provinces showed a minimum value in $\mathrm{JN}$ and then increased in the following order: $\mathrm{JJ}, \mathrm{GW}$, $\mathrm{CN}, \mathrm{JB}, \mathrm{GN}, \mathrm{CB}, \mathrm{GB}$, and $\mathrm{GG}$ with values ranging from 16.5 to $30.2 \mathrm{ppb}$.

To make a meaningful comparison of $\mathrm{NO}_{2}$ spatial distribution patterns, the $\mathrm{NO}_{2}$ data for each district were compared in terms of different statistical terms. To explain how those parameters differ between the districts, basic statistical parameters (mean, min., and max.) obtained for each district each month [throughout the study period $(\mathrm{N}=72)$ ] were re-summed for the derivation of their $2^{\text {nd }}$-stage average values, as shown in Fig. 2. The results of the majorcities group indicate that the highest maximum value occurred at SL with $51.0 \mathrm{ppb}$, and the 
Table 3. A statistical summary of $\mathrm{NO}_{2}$ measurement data from seven major cities and nine provinces in Korea from 1998 - 2003.

\begin{tabular}{ccccccc}
\hline \multirow{2}{*}{ Order } & City/Province & \multicolumn{5}{c}{$\mathrm{NO}_{2}$ concentration (ppb) } \\
\cline { 3 - 7 } & & Mean & SD & Min & Max & N \\
\hline 1 & SL & 34.7 & 6.38 & 19.4 & 48.1 & 72 \\
2 & BS & 25.3 & 5.22 & 14.5 & 36.9 & 72 \\
3 & DG & 27.0 & 6.47 & 14.0 & 43.0 & 72 \\
4 & IC & 27.0 & 4.31 & 17.0 & 36.7 & 72 \\
5 & GJ & 20.5 & 6.39 & 8.75 & 33.8 & 72 \\
6 & DJ & 21.4 & 7.46 & 8.67 & 42.3 & 72 \\
7 & US & 19.6 & 3.85 & 10.6 & 28.0 & 72 \\
8 & GG & 30.2 & 5.88 & 14.8 & 42.8 & 72 \\
9 & GW & 17.7 & 5.14 & 9.50 & 34.8 & 72 \\
10 & CB & 21.8 & 5.42 & 11.3 & 35.5 & 72 \\
11 & CN & 18.8 & 6.41 & 9.67 & 32.7 & 72 \\
12 & JB & 19.8 & 6.38 & 7.00 & 35.0 & 71 \\
13 & JN & 16.5 & 3.43 & 9.13 & 25.8 & 72 \\
14 & GB & 22.9 & 4.30 & 12.4 & 32.3 & 72 \\
15 & GN & 21.2 & 5.47 & 8.60 & 36.0 & 72 \\
16 & JJ & 17.5 & 6.79 & 5.00 & 36.0 & 72 \\
\hline & All & 22.6 & 5.58 & 11.3 & 36.2 & \\
\hline
\end{tabular}

lowest minimum at IC with $9.4 \mathrm{ppb}$. In the case of the provinces, the highest maximum value was found from GG with $48.7 \mathrm{ppb}$, and the lowest minimum from JN at $8.9 \mathrm{ppb}$.

To explain $\mathrm{NO}_{2}$ occurrence patterns for each individual district, frequency distribution patterns for $\mathrm{NO}_{2}$ occurrence were examined by sorting and classifying monthly datasets for each district. When the results of seven major cities are examined, maximum frequency normally occurs near $20 \sim 30 \mathrm{ppb}$. However, in the case of SL, it was much higher with a value of $40 \mathrm{ppb}$. In the case of the nine provinces, the maximum frequency was generally seen near $20 \sim 25 \mathrm{ppb}$. This frequency analysis clearly indicates that $\mathrm{NO}_{2}$ concentrations in major cities occur at values that are notably higher than those of the provinces. To further describe $\mathrm{NO}_{2}$ distributions for different districts, monthly mean $\mathrm{NO}_{2}$ concentrations were plotted as a function of time (Fig. 3). The results show that the largest mean value was found at SL (48.1 ppb), while the lowest mean was at $\mathrm{JJ}(5 \mathrm{ppb})$. The significantly enhanced $\mathrm{NO}_{2}$ levels in the capital SL and the surrounding GG province may also be related to the distinctively high population and traffic density in that region of the peninsula (Tables 4,5 ). This is easily understood, 


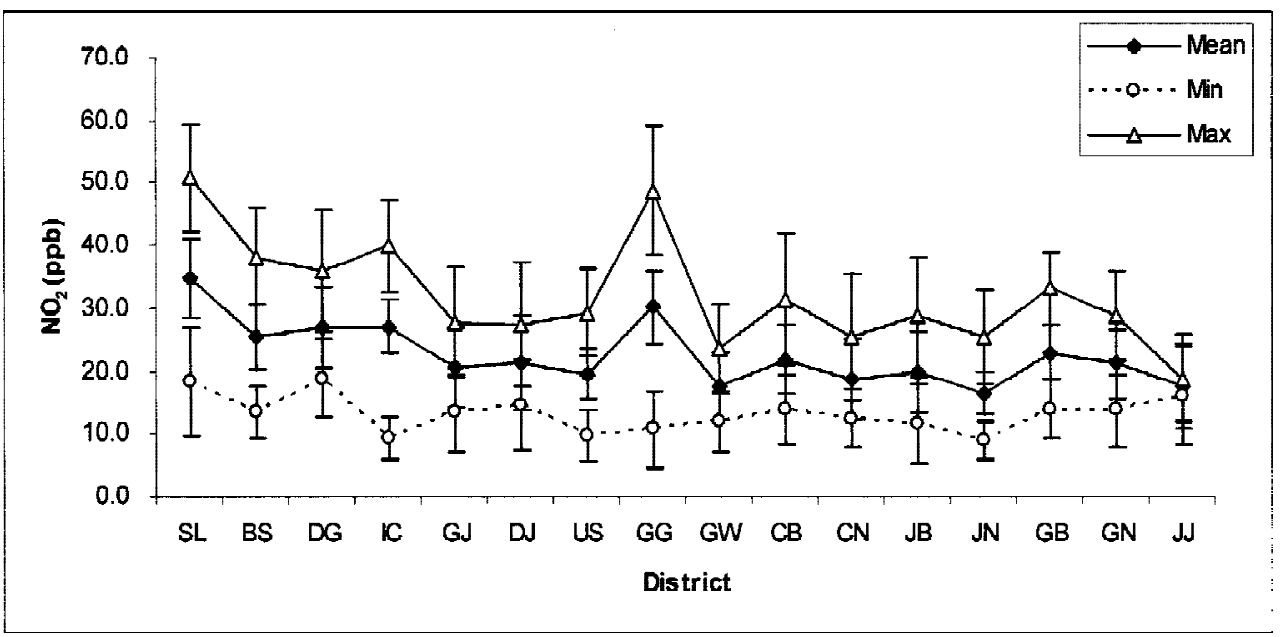

Fig. 2. Comparison of $\mathrm{NO}_{2}$ concentrations among seven major cities and nine provinces in Korea for the period covering 1998 to 2003. The secondstage mean values of three basic statistical terms (mean, min., and max.) were calculated using the monthly datasets for each of all 16 districts investigated in this study.

considering the high number of vehicles in these densely populated regions leading to significantly enhanced pollutant emissions (such as $\mathrm{NO}_{2}$ ). In general, vehicular pollution from both diesel and petrol motors remains a major problem, especially in the regions surrounding provincial capitals where the numbers of automobiles are highest (Goyal and Sidthartha 2003). Consideration for emission factors and vehicle activity has also demonstrated that the principal reasons for higher $\mathrm{NO}_{2} / \mathrm{NO}_{\mathrm{X}}$ ratios in city center areas are the high proportion of diesel vehicles, high flows of buses and taxis, and low vehicle speeds caused by traffic congestion (Carslaw et al. 2005). It is thus reasonable to conclude that the differences in observed $\mathrm{NO}_{2}$ spatial distribution patterns (e.g., between cities and provinces) are due primarily to anthropogenic activity levels.

\subsection{Seasonal Patterns}

To examine the effects of temporal factors on $\mathrm{NO}_{2}$ distribution patterns, the data from all 16 districts in Korea (seven cities and nine provinces) were compared for each season. As seen in Fig. 4, the seasonal mean values of most districts generally show a consistent and systematic pattern. Generally, they exhibit concentration changes in the following descending order: winter, spring, fall, and summer. However, on certain occasions (SL, IC, and GJ), the springtime concentrations tend to be the highest of all seasons. The most common pattern for most districts thus can be characterized as a notable increase during winter (and spring) and a significant drop in summer (and fall). 
a. Seven major cities

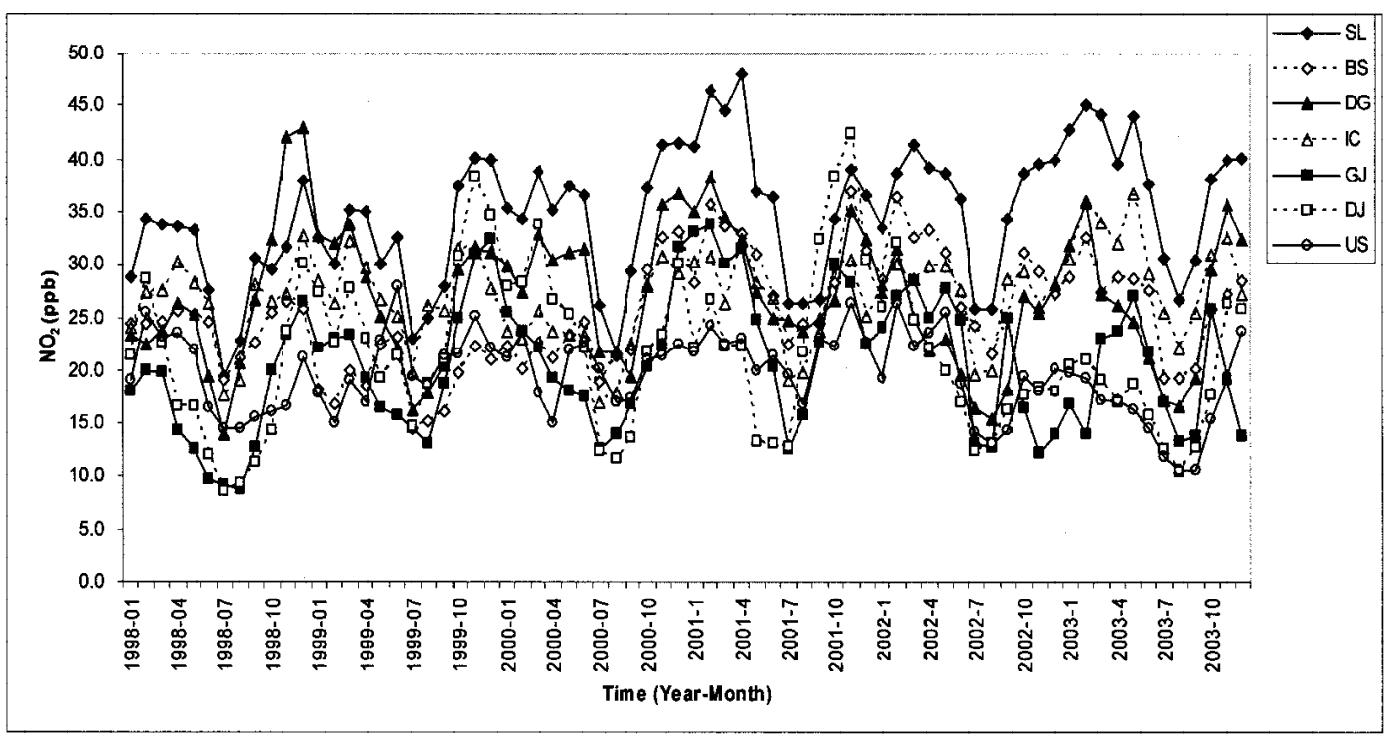

b. Nine provinces

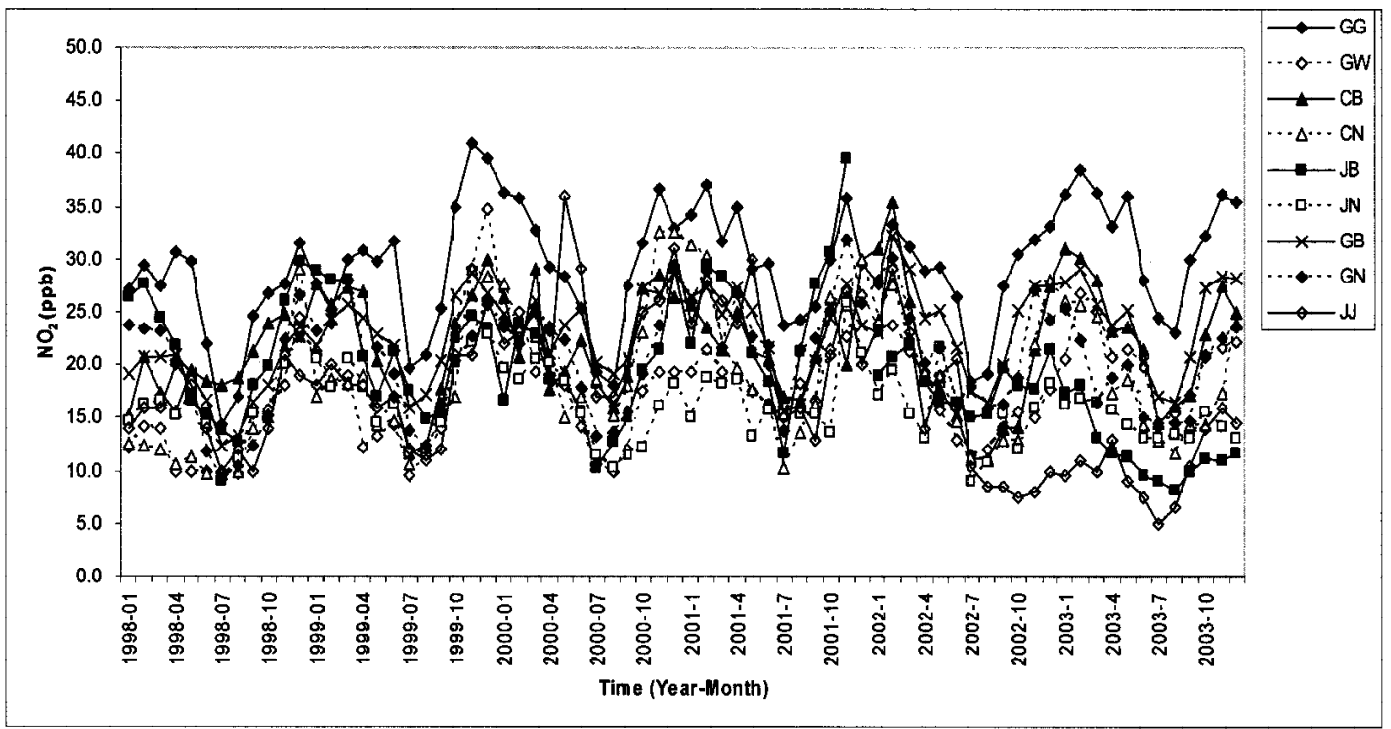

Fig. 3. Comparison of the monthly mean concentrations of $\mathrm{NO}_{2}(\mathrm{ppb})$ from major cities and provinces in Korea. 
Table 4. Comparison of Korean population density from 1998 to 2003 (all data given per 1000 persons).

a. Annual changes in population density in the entire S. Korea.

\begin{tabular}{ccccccc}
\hline Years & 1998 & 1999 & 2000 & 2001 & 2002 & 2003 \\
\hline Total Population & 47,174 & 47,543 & 47,977 & 48,289 & 48,518 & 48,824 \\
\hline
\end{tabular}

b. The population of all cities and provinces investigated in this study for the year 2002 .

\begin{tabular}{cccccccccc}
\hline City & SL & BS & DG & IC & GJ & DJ & US \\
\hline Total Population & 9,895 & 3,663 & 2,481 & 2,475 & 1,353 & 1,368 & 1,014 \\
\hline Province & GG & GW & CB & CN & JB & JN & GB & GN & JJ \\
\hline Total Population & 8,984 & 1,487 & 1,467 & 1,845 & 1,891 & 1,996 & 2,725 & 2,979 & 513 \\
\hline
\end{tabular}

Table 5. Total motor vehicle registration of districts in 2003 in Korea.

\begin{tabular}{crrrrr}
\hline City/Province & Car & Bus & Truck & Special - Car & Motor - Cycle \\
\hline SL & $2,143,502$ & 231,414 & 399,117 & 2,503 & 375,478 \\
BS & 667,191 & 85,833 & 195,601 & 6,741 & 107,180 \\
DG & 590,344 & 61,480 & 167,469 & 1,201 & 108,339 \\
IC & 546,016 & 74,383 & 150,128 & 3,824 & 54,023 \\
GJ & 295,525 & 35,996 & 82,087 & 1,022 & 33,204 \\
DJ & 359,121 & 37,443 & 83,521 & 993 & 28,053 \\
US & 269,640 & 25,979 & 61,712 & 1,685 & 38,470 \\
GG & $2,333,457$ & 293,559 & 598,809 & 7,138 & 259,602 \\
GW & 329,491 & 45,843 & 124,486 & 1,420 & 52,484 \\
CB & 313,032 & 41,767 & 120,562 & 2,125 & 75,662 \\
CN & 383,395 & 50,529 & 166,384 & 2,125 & 115,012 \\
JB & 365,923 & 45,326 & 154,162 & 1,615 & 84,053 \\
JN & 324,443 & 49,377 & 175,657 & 3,871 & 99,573 \\
GB & 573,070 & 68,493 & 244,201 & 4,022 & 158,208 \\
GN & 660,825 & 80,820 & 235,206 & 4,215 & 119,674 \\
JJ & 123,948 & 18,387 & 57,305 & 336 & 21,178 \\
\hline
\end{tabular}


a. Seven major cities

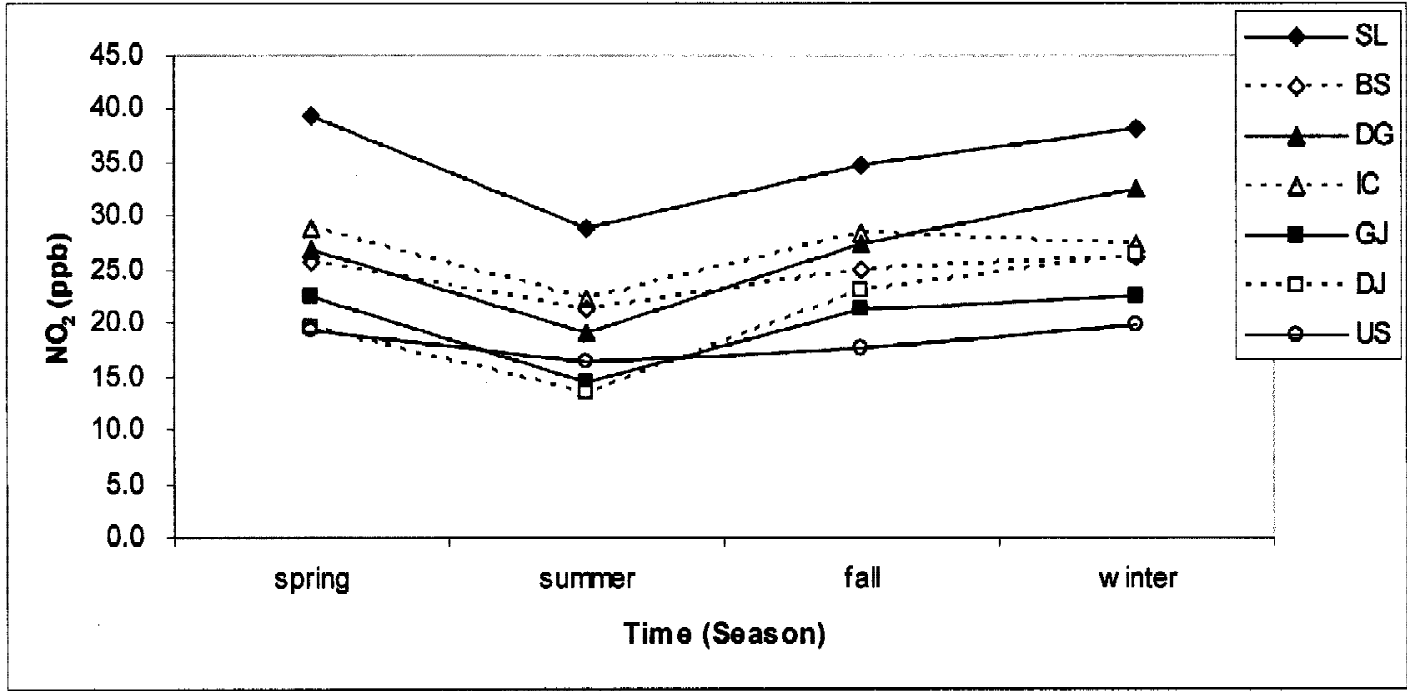

b. Nine provinces

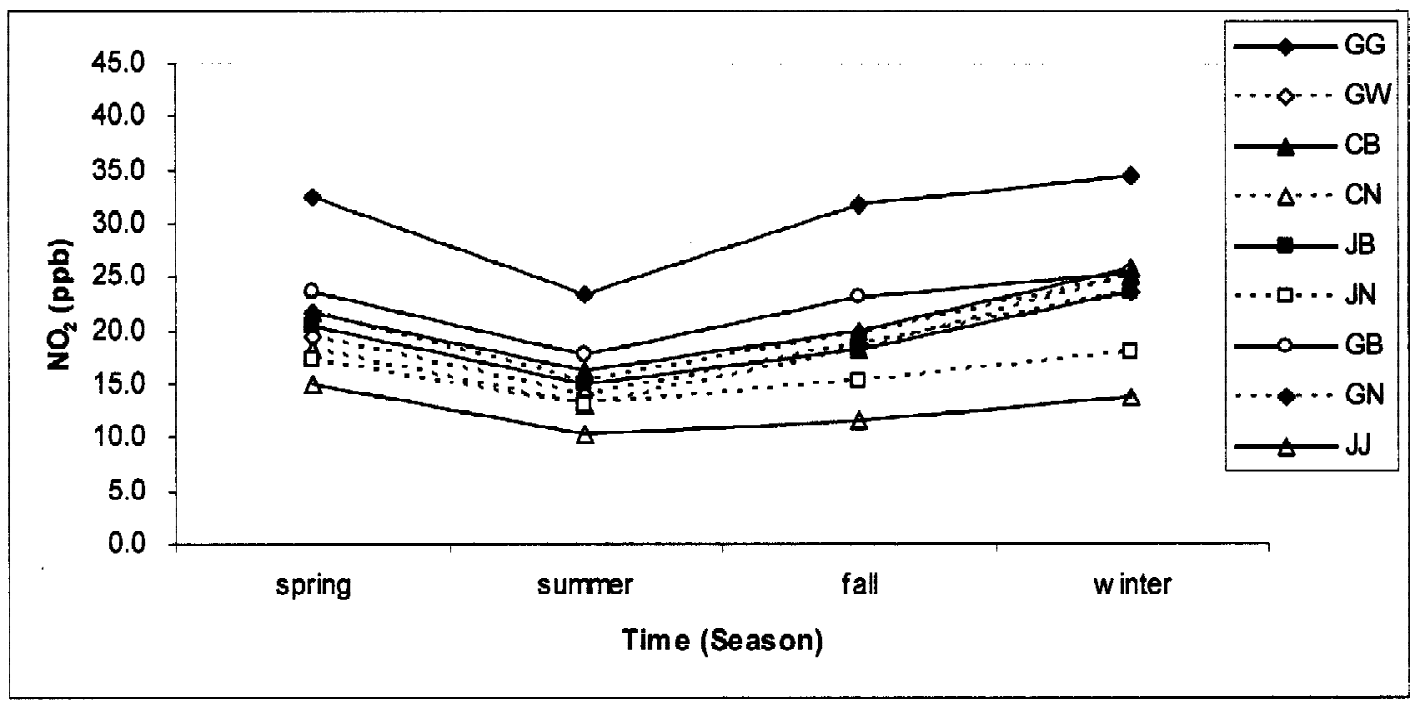

Fig. 4. Comparison of seasonal mean concentrations of $\mathrm{NO}_{2}(\mathrm{ppb})$ measured from both major cities and provinces. 
Although there tends to be a moderate difference in $\mathrm{NO}_{2}$ distributions between spring and fall, those seen between winter and summer are quite dramatic. For example, the wintertime mean value at SL was $38.2 \mathrm{ppb}$, while its summertime counterpart showed a $24 \%$ reduction at $28.9 \mathrm{ppb}$. There are many previous studies showing similar temporal patterns with high $\mathrm{NO}_{2}$ concentrations being found during winter and lower values during summer (Hargreaves et al. 2005, Gupta et al. 2003). Observed seasonality of $\mathrm{NO}_{2}$ distribution is attributable to a number of factors including higher fuel usage for heating (Gupta et al. 2003). If the results among seven major cities are compared, the highest seasonal mean value was recorded in SL during spring at $39.3 \mathrm{ppb}$ (winter value: $38.2 \mathrm{ppb}$ ). On the other hand, the lowest value was seen in DJ during the summer (13.4 ppb). If the results are compared among the nine provinces, the highest and lowest seasonal mean concentrations were found in GG (winter $34.3 \mathrm{ppb}$ ) and JJ (summer $10.4 \mathrm{ppb}$ ), respectively. The winter (or spring) highs could also be linked to such factors as increased central heating. Moreover, the high winter concentrations of $\mathrm{NO}_{2}$ could be enhanced further by a reduction in photochemical reactions in which $\mathrm{NO}_{2}$ and hydroxyl $(\mathrm{OH})$ radicals combine to form nitric acid $\left(\mathrm{HNO}_{3}\right)$ (Derwent et al. 1995). In terms of summertime variability, strong rains can contribute to lower $\mathrm{NO}_{2}$ concentrations. Such seasonal trends have been demonstrated previously, in particular the efficient removal of $\mathrm{NO}_{3}{ }^{-}$from the atmosphere was principally attributed to summer rains by Hong et al. (2002). In addition, the mean mixing height layer, which is reduced to its minimal level in winter (or spring), can also be a very important factor, as it controls the transport pattern of $\mathrm{NO}_{2}$ through the seasons (Shahgedanova et al. 1999).

\subsection{Annual Patterns}

As $\mathrm{NO}_{2}$ measurements were made continuously over several years, these data can be used to evaluate trends over a relatively long-term period. As seen in Fig. 5, the results of longterm analysis indicate that there are some variations in $\mathrm{NO}_{2}$ distribution patterns throughout the five-year period for all 16 districts. The highest mean values were typically found at big cities and densely populated urban areas (e.g., SL and GG). On the other hand, the lowest values were seen most frequently from those with wide rural areas or where vehicular activities and industrialization are low (such as JJ and JN). When long-term $\mathrm{NO}_{2}$ distribution patterns among the seven major cities are compared, the most prominent pattern exists at SL where a gradual increase from 30.1 (1998) to $38.5 \mathrm{ppb}$ (2003) is observed. On the other hand, the $\mathrm{NO}_{2}$ distributions from the six remaining cities tend to fluctuate, with mean values ranging from 16.1 (GJ) to $29.9 \mathrm{ppb}$ (IC). Although we were not able to obtain entire annual datasets for detailed analysis of vehicular registration patterns (Table 5), those available for the year 2003 indicate that patterns for SL and GG area are not easy to predict. While there exist some reports regarding efforts to control $\mathrm{NO}_{2}$ emissions (e.g., Dixon et al. 2001), patterns in SL suggest that many control policies developed in Korea may not be effective in reducing $\mathrm{NO}_{2}$ concentration levels, especially in large urban areas.

The results of this comparison indicate the possibility that fast growth in vehicular population, prominent in large urban areas such as SL, may have led to a corresponding increase in vehicular emissions of $\mathrm{NO}_{2}$. There has been a marked increase in the number of 
a. Seven major cities

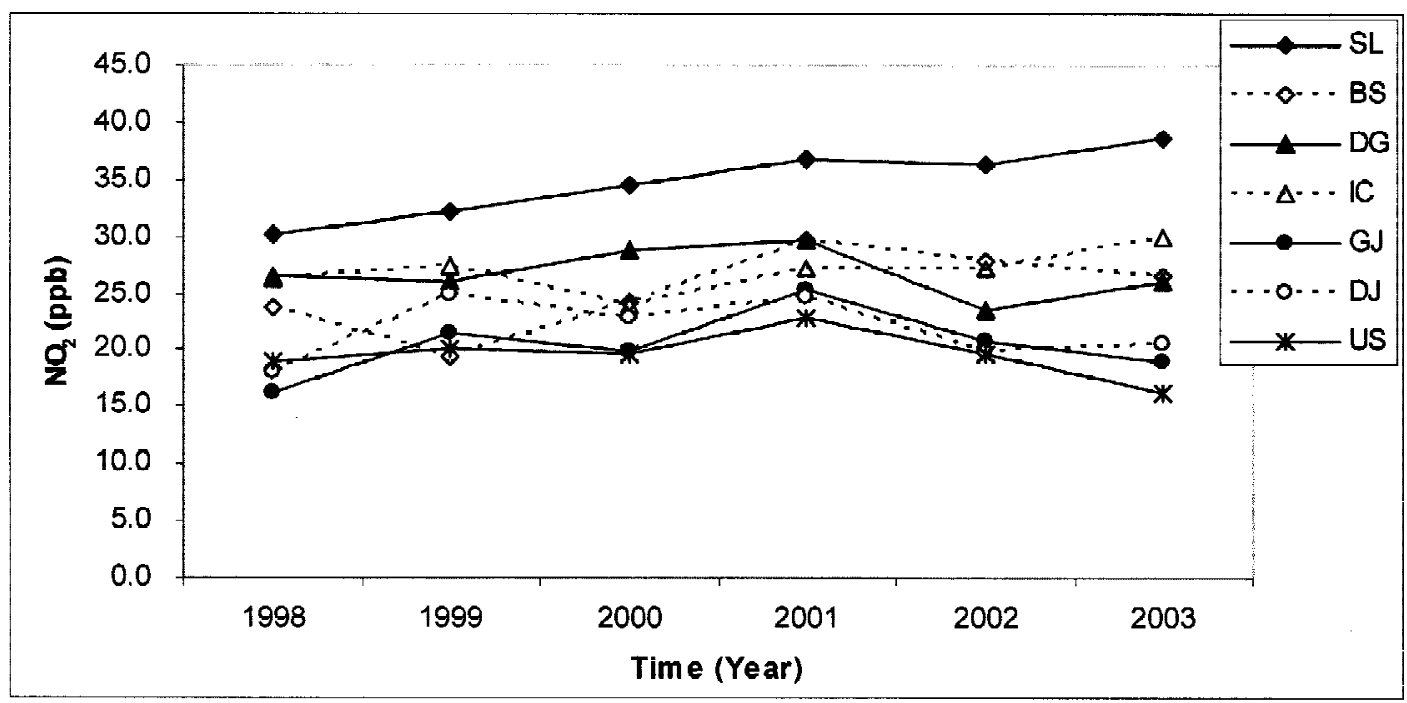

b. Nine provinces

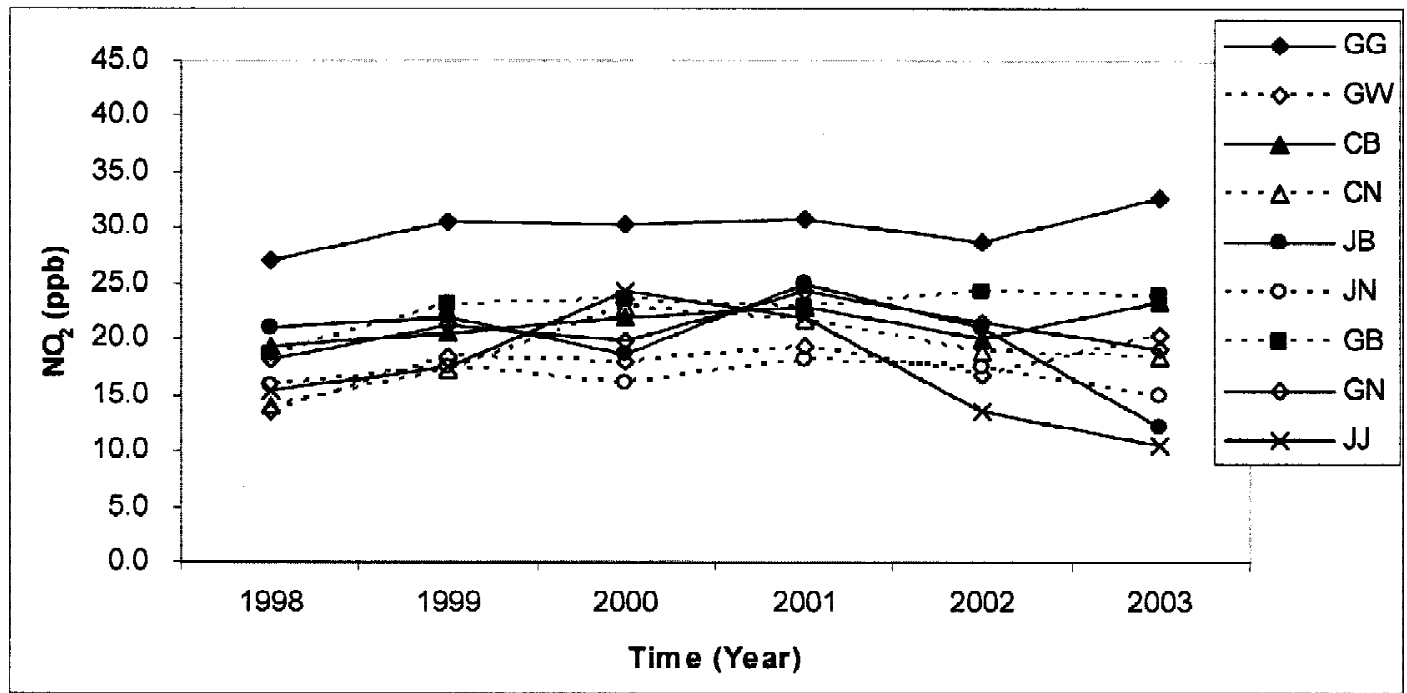

Fig. 5. Comparison of the yearly mean concentrations of $\mathrm{NO}_{2}(\mathrm{ppb})$ from the major cities and provinces. 
vehicle registrations in SL, and this corresponds to increased population (Fig. 6 and Table 5). Such factors linked together can promote increased consumption of fossil fuels (Fig. 7), leading to enhanced $\mathrm{NO}_{2}$ emissions. Except for the case of GG, with an increasing trend in annual $\mathrm{NO}_{2}$ levels [27.2 (1998) to $32.7 \mathrm{ppb}$ (2003)], the remaining provinces generally exhibit moderate changes with mean values of 10.5 (JJ) to $24.3 \mathrm{ppb}(\mathrm{GN})$ during the entire study period. Another readily observable trend is that concentrations in major cities are systematically higher

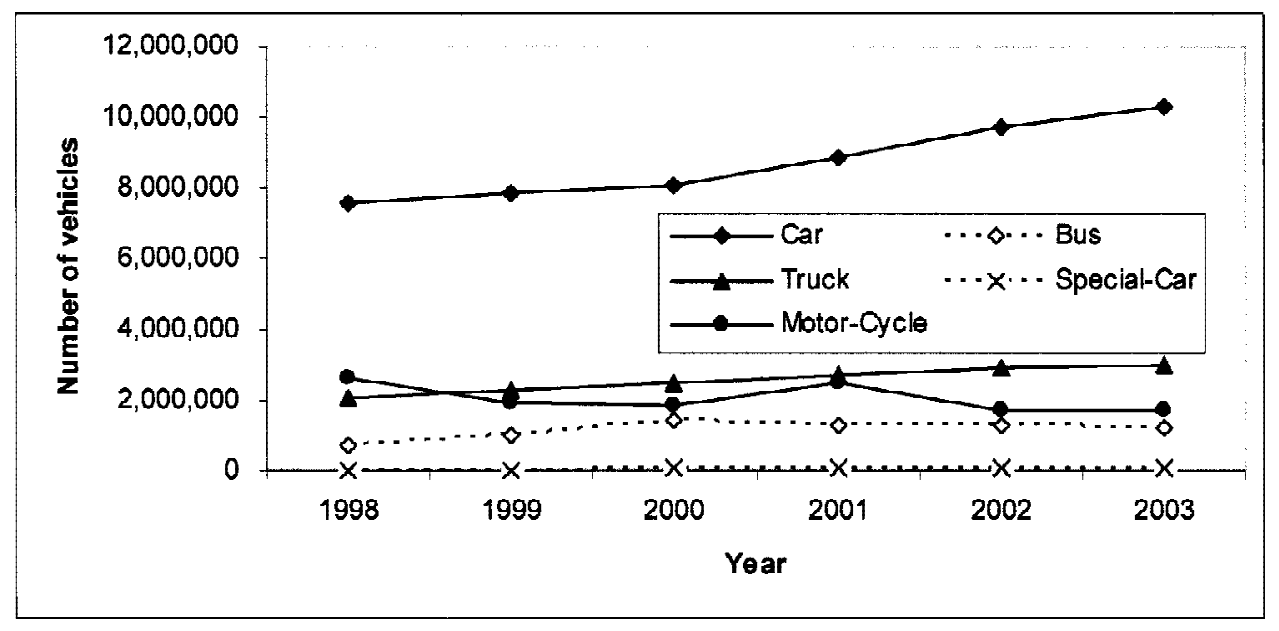

Fig. 6. Annual trends of total motor vehicle registration recorded in Korea. (years 1998 to 2003) (MOCT 2004)

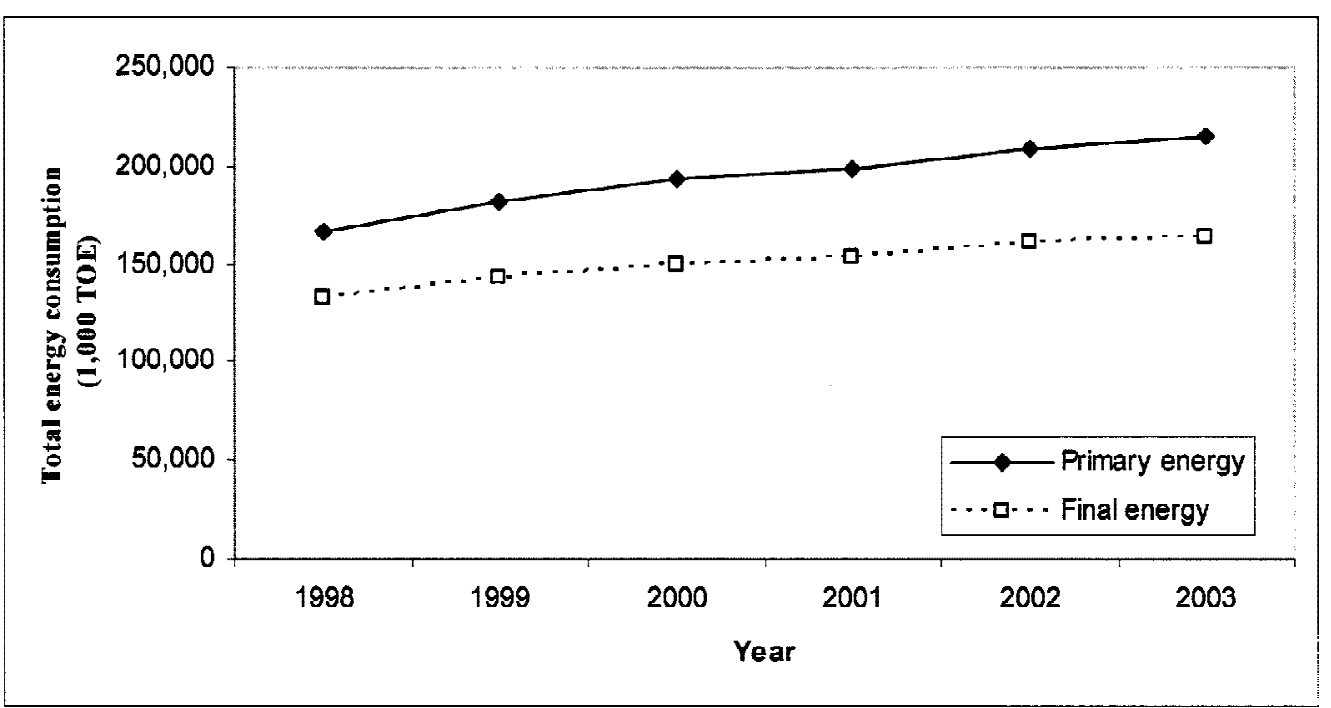

Fig. 7. Annual trends of total energy consumption recorded in Korea. (years 1998 to 2003) (KMOE 2004) 
than those of the provinces. This observation supports previous finding that gradual increases in $\mathrm{NO}_{2}$ emissions have coincided with increased urbanization and industrialization in urban areas (Jo et al. 2000).

\subsection{Factors affecting $\mathrm{NO}_{2}$ distribution}

To study factors affecting distribution characteristics of $\mathrm{NO}_{2}$, we investigated spatial relationships among different districts using monthly $\mathrm{NO}_{2}$ datasets. The relationships among all districts were checked after dividing them into three data groups A (city - to - city), B (province - to - province), and C (city - to - province) (Table 6). The strengths of correlations among the matching district pairs were estimated arbitrarily by dividing all results into five different classes based on the magnitude of probability (P) such as: (1) no class (the weakest correlation range): $\mathrm{P} \geq 10^{-3}$; (2) class I (weak correlation): $10^{-5} \leq \mathrm{P}<10^{-3}$; (3) class II: $10^{-10} \leq \mathrm{P}<10^{-5}$; (4) class III: $10^{-15} \leq \mathrm{P}<10^{-10}$; and (5) class IV (the strongest correlation range): $\mathrm{P}<10^{-15}$. The results of this correlation analysis are summarized to allow direct comparison among different grouping schemes (Table 7). Results for data group A indicate that for a total of 21 correlation cases, SL generally exhibits the highest correlations with the remaining six cities, especially with IC (class IV). It is in fact found that the closer the distance between the sites, the stronger the correlation is. It should also be noted that the strongly correlated pairs are generally found between sites of high $\mathrm{NO}_{2}$ concentrations. In the case of group $\mathrm{B}$, the strongly correlated pairs tend to be seen between GN and many other provinces. In this group, the weakest correlations are generally found where the $\mathrm{NO}_{2}$ concentrations are low, such as JJ and JB. In the case of group C, with a total of 63 matching cases, it was seen that 3 cases of the strongest correlation (class IV) exist, while 10 cases do not belong to any class (no class). The weakly correlated pairs in this $\mathrm{C}$ group are found most abundantly from the pairs between $\mathrm{JJ}$ and the seven cities. The results of this correlation analysis thus indicate that there are many cases of strongly correlated pairs from all data groups, while the patterns tend to be distinguished by such factors as the level of man-made activities for a given city (or province).

\section{CONCLUSIONS}

In this study, spatio-temporal distribution characteristics of $\mathrm{NO}_{2}$ were investigated using the datasets measured routinely from air quality monitoring stations located throughout the 16 districts of Korea during 1998 to 2003. The spatial distribution patterns for the study period were generally characterized by the highest $\mathrm{NO}_{2}$ concentration being at the capital, SL (city), and the lowest concentration being at the remote islands area of $\mathrm{JN}$ (province). If the distribution patterns are compared among different districts, the occurrence pattern of $\mathrm{NO}_{2}$ datasets in the cities peaked near $20 \sim 30 \mathrm{ppb}$ (with the prominent case of SL at $40 \mathrm{ppb}$ ), while those of the provinces were generally at $20 \sim 25 \mathrm{ppb}$ range. Moreover, examination of seasonal patterns indicates that the highest mean values were typically found during wintertime followed by spring, fall, and summer. The cause of these seasonal patterns can be attributed to such factors as the combined effect of fossil fuel consumption patterns and meteorological conditions. 
Table 6. Results of correlation analysis on $\mathrm{NO}_{2}$ concentration datasets: their relationships are compared after being grouped into three different categories: (A) city - to - city, (B) province - to - province, (C) city - to - province.

a. Group A (city - to - city)

\begin{tabular}{|c|c|c|c|c|c|c|c|c|}
\hline & & SL & BS & DG & IC & GJ & DJ & US \\
\hline \multirow[t]{3}{*}{ SL } & $r$ & 1 & 0.706 (II1) & 0.643 (II) & 0.793 (IV) & 0.654 (II) & $0.469(1)$ & $0.43(I)$ \\
\hline & $P$ & & $3.91 \mathrm{E}-12$ & $1.06 \mathrm{E}-09$ & $8.50 \mathrm{E}-17$ & $4,38 \mathrm{E}-10$ & $3.20 \mathrm{E}-05$ & $1.62 \mathrm{E}-04$ \\
\hline & N & 72 & 72 & 72 & 72 & 72 & 72 & 72 \\
\hline \multirow[t]{3}{*}{ BS } & $\mathbf{r}$ & & 1 & $0.452(\mathrm{I})$ & 0.52 (II) & $0.473(\mathrm{I})$ & $0.277(0)$ & $0.438(\mathrm{I})$ \\
\hline & $\mathrm{P}$ & & & $6.64 \mathrm{E}-05$ & $2.78 \mathrm{E}-06$ & $2.68 \mathrm{E}-05$ & $1.85 \mathrm{E}-02$ & $1.18 \mathrm{E}-04$ \\
\hline & $\mathbf{N}$ & & 72 & 72 & 72 & 72 & 72 & 72 \\
\hline \multirow[t]{3}{*}{ DG } & $\mathbf{r}$ & & & 1 & 0.536 (II) & 0.541 (II) & 0.621 (II) & $0.396(\mathrm{I})$ \\
\hline & $\mathbf{p}$ & & & & $1.19 \mathrm{E}-06$ & $9.02 \mathrm{E}-07$ & $5.59 \mathrm{E}-09$ & $5.70 \mathrm{E}-04$ \\
\hline & $\mathbf{N}$ & & & 72 & 72 & 72 & 72 & 72 \\
\hline \multirow[t]{3}{*}{ IC } & $\mathbf{r}$ & & & & 1 & $0.562(\mathrm{II})$ & $0.404(\mathrm{I})$ & $0.284(0)$ \\
\hline & $P$ & & & & & $2.70 \mathrm{E}-07$ & $4.29 \mathrm{E}-04$ & $1.50 \mathrm{E}-02$ \\
\hline & $\mathbf{N}$ & & & & 72 & 72 & 72 & 72 \\
\hline \multirow[t]{3}{*}{ GJ } & $\mathbf{r}$ & & & & & 1 & 0.653 (II) & $0.438(\mathrm{I})$ \\
\hline & $\mathrm{P}$ & & & & & & $4.75 \mathrm{E}-10$ & $1.18 \mathrm{E}-04$ \\
\hline & $\mathbf{N}$ & & & & & 72 & 72 & 72 \\
\hline \multirow[t]{3}{*}{ DJ } & $\mathbf{r}$ & & & & & & 1 & 0.61 (II) \\
\hline & $P$ & & & & & & & $1.22 \mathrm{E}-08$ \\
\hline & $\mathbf{N}$ & & & & & & 72 & 72 \\
\hline \multirow[t]{3}{*}{ US } & $\mathbf{r}$ & & & & & & & 1 \\
\hline & $\mathrm{P}$ & & & & & & & \\
\hline & $\mathbf{N}$ & & & & & & & 72 \\
\hline
\end{tabular}

b. Group B (province - to - province)

\begin{tabular}{|c|c|c|c|c|c|c|c|c|c|c|}
\hline & & $G ;$ & (GW & CB & $\mathrm{CN}$ & JB & JN & (BB & GN & .J.J \\
\hline \multirow[t]{3}{*}{ GG } & $\mathbf{r}$ & 1 & 0.76 (III) & 0.651 (II) & 0.705 (III) & $0.333(0)$ & $0.619(1)$ & 0.839 (IV) & $0.677(\mathrm{nI})$ & $0.358(0)$ \\
\hline & $\mathrm{P}$ & & $8.51 \mathrm{E}-15$ & $5.59 \mathrm{E}-10$ & $4.32 \mathrm{E}-12$ & 4.53E-03 & $6.46 \mathrm{E}-09$ & $2.74 \mathrm{E}-20$ & $6.12 \mathrm{E}-11$ & $2.01 \mathrm{E}-03$ \\
\hline & $\mathrm{N}$ & 72 & 72 & 72 & 72 & 71 & 72 & 72 & 72 & 72 \\
\hline \multirow[t]{3}{*}{ GW } & $\mathbf{r}$ & & 1 & 0.695 (III) & 0.733 (III) & $0.306(0)$ & $0.649(\mathrm{iT})$ & $0.665(\mathrm{II})$ & $0.616(11)$ & $0.336(0)$ \\
\hline & $p$ & & & $1.15 \mathrm{E}-11$ & $2.20 \mathrm{E}-13$ & $9.43 \mathrm{E}-03$ & $6.57 \mathrm{t}-10$ & $1.75 \mathrm{k}-10$ & $8.01 \mathrm{E}-09$ & $3.89 \mathrm{E}-03$ \\
\hline & $\mathbf{N}$ & & 72 & 72 & 72 & 71 & 72 & 72 & 72 & 72 \\
\hline \multirow[t]{3}{*}{ CB } & $r$ & & & 1 & 0.748 (III) & $0.289(0)$ & 0.514 (II) & 0.722 (III) & 0.61 (II) & 0.414 (I) \\
\hline & $\mathrm{P}$ & & & & $3.80 \mathrm{E}-14$ & $1.45 \mathrm{E}-02$ & $3.79 \mathrm{E}-06$ & $7.39 \mathrm{E}-13$ & $1.22 \mathrm{E}-08$ & $2.97 \mathrm{E}-04$ \\
\hline & $\mathbf{N}$ & & & 72 & 72 & 71 & 72 & 72 & 72 & 72 \\
\hline \multirow[t]{3}{*}{$\mathrm{CN}$} & $\mathrm{r}$ & & & & 1 & $0.433(\mathrm{~T})$ & 0.5599 (II) & 0.756 (III) & $0.713(\mathrm{III})$ & 0.499 (II) \\
\hline & $P$ & & & & & $1.60 \mathrm{E}-04$ & $3.23 \mathrm{E}-07$ & 1.41E-14 & $1.91 \mathrm{E}-12$ & 7.97E-06 \\
\hline & $\mathrm{N}$ & & & & 72 & 71 & 72 & 72 & 72 & 72 \\
\hline \multirow[t]{3}{*}{$\mathrm{JB}$} & $r$ & & & & & 1 & 0.633 (II) & $0.345(0)$ & 0.692 (III) & 0.533 (II) \\
\hline & $\mathrm{p}$ & & & & & & $2.98 \mathrm{E}-09$ & $3.20 \mathrm{E}-03$ & $2.14 \mathrm{E}-11$ & $1.66 \mathrm{E}-06$ \\
\hline & $\mathrm{N}$ & & & & & 71 & 71 & 71 & 71 & 71 \\
\hline \multirow[t]{3}{*}{$J N$} & $\mathbf{r}$ & & & & & & 1 & 0.524 (II) & 0.689 (III) & 0.5 (II) \\
\hline & $P$ & & & & & & & $2.26 \mathrm{E}-06$ & $2.04 \mathrm{E}-11$ & $7.60 \mathrm{E}-06$ \\
\hline & $\mathrm{N}$ & & & & & & 72 & 72 & 72 & 72 \\
\hline \multirow[t]{3}{*}{ GB } & $\mathbf{r}$ & & & & & & & 1 & 0.763 (III) & 0.488 (1) \\
\hline & $P$ & & & & & & & & $5.78 \mathrm{E}-15$ & 1.35E-05 \\
\hline & $\mathbf{N}$ & & & & & & & 72 & 72 & 72 \\
\hline \multirow[t]{3}{*}{ GN } & $\mathbf{r}$ & & & & & & & & 1 & 0.561 (II) \\
\hline & $P$ & & & & & & & & & $2.87 \mathrm{E}-07$ \\
\hline & $\mathrm{N}$ & & & & & & & & 72 & 72 \\
\hline \multirow[t]{2}{*}{ JJ } & $\mathbf{r}$ & & & & & & & & & 1 \\
\hline & $P$ & & & & & & & & & 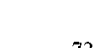 \\
\hline
\end{tabular}


Table 6. Continued.

c. Group C (city - to - province)

\begin{tabular}{|c|c|c|c|c|c|c|c|c|c|c|}
\hline & & GG & GW & CB & $\mathrm{CN}$ & $\mathrm{JB}$ & $\mathrm{JN}$ & GB & GN & $\mathrm{JJ}$ \\
\hline \multirow[t]{3}{*}{ SL } & $r$ & 0.872 (IV) & 0.655 (II) & 0.604 (II) & 0.669 (II) & $0.288(0)$ & 0.525 (II) & 0.858 (IV) & 0.65 (II) & $0.371(0)$ \\
\hline & $\mathrm{P}$ & $1.49 \mathrm{E}-23$ & $4.04 \mathrm{E}-10$ & $1.85 \mathrm{E}-08$ & $1.24 \mathrm{E}-10$ & $1.48 E_{-}-02$ & $2.14 \mathrm{E}-06$ & $4.55 \mathrm{E}-22$ & $6.07 \mathrm{E}-10$ & 1.33E-03 \\
\hline & $\mathbf{N}$ & 72 & 72 & 72 & 72 & 71 & 72 & 72 & 72 & 72 \\
\hline \multirow[t]{3}{*}{ BS } & $\mathbf{r}$ & $0.509(\mathrm{II})$ & $0.361(0)$ & $0.394(\mathrm{I})$ & 0.513 (II) & $0.29(0)$ & $0.244(0)$ & 0.607 (II) & 0.549 (II) & $0.338(0)$ \\
\hline & $P$ & $4.87 E-06$ & $1.83 \mathrm{E}-03$ & $6.12 \mathrm{E}-04$ & $3.98 \mathrm{E}-06$ & $1.41 E-02$ & $3.88 \mathrm{E}-02$ & $1.51 \mathrm{E}-08$ & $5.75 E-07$ & $3.67 \mathrm{E}-03$ \\
\hline & $\mathbf{N}$ & 72 & 72 & 72 & 72 & 71 & 72 & 72 & 72 & 72 \\
\hline \multirow[t]{3}{*}{ DG } & $\mathbf{r}$ & $0.663(\mathrm{II})$ & $0.63(\mathrm{II})$ & 0.705 (III) & 0.708 (III) & 0.552 (II) & 0.688 (III) & 0.682 (III) & 0.719 (III) & $0.57(\mathrm{II})$ \\
\hline & $P$ & $2.07 \mathrm{E}-10$ & $2.88 \mathrm{E}-09$ & $4.32 \mathrm{E}-12$ & $3.19 \mathrm{E}-12$ & $5.85 \mathrm{E}-07$ & $2.24 \mathrm{E}-11$ & $3.89 \mathrm{E}-11$ & $2.60 \mathrm{E}-12$ & $1.67 \mathrm{E}-07$ \\
\hline & $\mathbf{N}$ & 72 & 72 & 72 & 72 & 71 & 72 & 72 & 72 & 72 \\
\hline \multirow[t]{3}{*}{ IC } & $\mathbf{r}$ & $0.76(\mathrm{III})$ & 0.531 (II) & 0.547 (II) & $0.452(\mathrm{I})$ & $0.282(0)$ & $0.457(\mathrm{I})$ & 0.69 (III) & 0.495 (II) & $0.118(0)$ \\
\hline & $\mathrm{P}$ & $8.51 \mathrm{E}-15$ & $1.56 \mathrm{E}-06$ & $6.45 \mathrm{E}-07$ & $6.64 \mathrm{E}-05$ & $1.72 \mathrm{E}-02$ & $5.38 \mathrm{E}-05$ & $1.85 \mathrm{E}-11$ & $9.67 \mathrm{E}-06$ & $3.23 \mathrm{E}-01$ \\
\hline & $\mathbf{N}$ & 72 & 72 & 72 & 72 & 71 & 72 & 72 & 72 & 72 \\
\hline \multirow[t]{3}{*}{ GJ } & $\mathbf{r}$ & $0.616(11)$ & 0.645 (11) & $0.474(\mathrm{I})$ & 0.635 (II) & 0.559 (II) & 0.59 (11) & 0.631 (II) & 0.653 (II) & 0.567 (II) \\
\hline & $\mathrm{P}$ & $8.01 \mathrm{E}-09$ & $9.05 \mathrm{E}-10$ & $2.56 \mathrm{E}-05$ & $1.97 \mathrm{E}-09$ & $3.92 \mathrm{E}-07$ & $4.73 E-08$ & $2.67 \mathrm{E}-09$ & $4.75 E-10$ & $2.00 \mathrm{E}-07$ \\
\hline & $\mathbf{N}$ & 72 & 72 & 72 & 72 & 71 & 72 & 72 & 72 & 72 \\
\hline \multirow[t]{3}{*}{ DJ } & $\mathbf{r}$ & 0.617 (II) & $0.692(\mathrm{HII})$ & 0.553 (II) & 0.644 (II) & 0.707 (III) & $0.733(\mathrm{III})$ & 0.624 (II) & 0.777 (IV) & 0.55 (II) \\
\hline & $\mathrm{P}$ & $7.46 \mathrm{E}-09$ & $1.53 \mathrm{E}-11$ & $4.58 \mathrm{E}-07$ & $9.79 \mathrm{E}-10$ & $5.03 \mathrm{E}-12$ & $2.20 \mathrm{E}-13$ & 4.49E-09 & $8.75 \mathrm{E}-16$ & $5.44 \mathrm{E}-07$ \\
\hline & $\mathbf{N}$ & 72 & 72 & 72 & 72 & 71 & 72 & 72 & 72 & 72 \\
\hline \multirow[t]{3}{*}{ US } & $\mathbf{r}$ & $0.492(\mathrm{D})$ & $0.291(0)$ & $0.30\}(0)$ & $0.438(\mathrm{I})$ & 0.529 (II) & 0.455 (I) & 0.529 (II) & $0.56(\mathrm{II})$ & 0.581 (II) \\
\hline & $\mathrm{P}$ & $1.12 \mathrm{E}-05$ & $1.31 \mathrm{E}-02$ & $1.02 \mathrm{E}-02$ & $1.18 \mathrm{E}-04$ & $2.06 \mathrm{E}-06$ & $5.85 E-05$ & $1.73 \mathrm{E}-06$ & $3.04 \mathrm{E}-07$ & $8.43 \mathrm{E}-08$ \\
\hline & $\mathbf{N}$ & 72 & 72 & 72 & 72 & 71 & 72 & 72 & 72 & $\quad 72$ \\
\hline
\end{tabular}

Table 7. Evaluation of correlation analysis results for all $\mathrm{NO}_{2}$ concentration data sets. All data were collected from seven cities and nine provinces in Korea during the study period. Refer to Table 6 for the original results of the correlation analysis.

\begin{tabular}{cccc}
\hline Group & A & B & C \\
Class & & & \\
\hline None & 2 & 6 & 10 \\
I & 8 & 3 & 7 \\
II & 9 & 12 & 33 \\
III & 1 & 14 & 10 \\
IV & 1 & 1 & 3 \\
\hline All groups & 21 & 36 & 63 \\
\hline
\end{tabular}

Examinations of the annual patterns also indicate that high $\mathrm{NO}_{2}$ concentrations typically occur at big cities and their vicinities, where rapid urbanization and high industrialization exist. The results of correlation analysis among all 16 districts show that stronger correlations predominate in areas of higher $\mathrm{NO}_{2}$ concentration. In addition, the distance between districts can also act as an important factor in determining the strength of correlation. The overall results of this analysis thus clearly indicate that enhanced man-made activities in more urbanized re- 
gions contribute significantly to changes in $\mathrm{NO}_{2}$ levels on the Korean peninsula. Emission standards as they relate to pollution sources need to be elaborated on in order to further control pollutants such as $\mathrm{NO}_{2}$. Tactics such as placing emission standards on newly manufactured vehicles, in-use vehicles, and fuel production standards may be the most effective methods for efficiently reducing vehicle exhaust air pollution.

Acknowledgements This work was supported by a Korea Research Foundation Grant (KRF2005-201-C00045).

\section{REFERENCES}

Carslaw, D. C., and S. D.Beevers, 2005: Development of an urban inventory for road transport emissions of $\mathrm{NO}_{2}$ and comparison with estimates derived from ambient measurements. Atmos. Environ., 39, 2049-2059.

Derwent, R. G., D. R. Middleton, R. A. Field, M. E. Goldstone, J. N. Lester, and R. Perry, 1995: Analysis and interpretation of air quality data from an urban roadside location in central London over the period from July 1991 to July 1992. Atmos. Environ., 29, 923 946.

Dixon, J., D. R. Middleton, and R. G. Derwent, 2001: Sensitivity of nitrogen dioxide concentrations to oxides of nitrogen controls in the United Kingdom. Atmos. Environ., 35, 3715-3728.

Goyal, P., and Sidhartha, 2003: Present scenario of air quality in Delhi: a case study of CNG implementation. Atmos. Environ., 37, 5423-5431.

Gupta, A., R. Kumar, K. M. Kumari, S. S. Srivastava, 2003: Measurement of $\mathrm{NO}_{2}, \mathrm{HNO}_{3}$, $\mathrm{NH}_{3}$ and $\mathrm{SO}_{2}$ and related particulate matter at a rural in Rampur, India.Atmos. Environ., 37, 4837-4846.

Hargreaves, P. R., J. U. Smith, S. Young, and K. W. T. Goulding, 2005: Development of an empirical model to predict nitrogen dioxide concentratins from weather variables for sites across the UK. Atmos. Environ., 39, 409-417.

Hoek, G., B. Brunekreef, S. Goldbohm, P. Fischer, and P. A. van den Brandt, 2002: Association between mortality and indicators of traffic-related air pollution in the Netherlands: a cohort study. Lancet, 360, 1203-1209.

Hong, Y. M., B. K. Lee, K. J. Park, M. H. Kang, Y. R. Jung, D. S. Lee, and M. G. Kim, 2002: Atmospheric nitrogen and sulfur containing compounds for three sites of South Korea. Atmos. Environ., 36, 3485-3494.

Jo, W. K., I. H. Yoon, and C. W. Nam, 2000: Analysis of air pollution in two major Korean cities: trends, seasonal variations, daily 1 - hour maximum versus other hour-based concentrations, and standard exceedances. Environ. Poll., 110, 11-18.

Lee, D. S., M. K. Holland, and N. Falla, 1996: The potential impact of ozone on materials in the UK. Atmos. Environ., 30, 1053-1065.

Mackenzie, A. R., R. M. Harrison, I. Colbeck, P. A. Clark, and R. H. Varey, 1995: The ozone increments in urban plumes. Sci. Total Environ., 159, 91-99. 
Mazzeo, N. A., L. E. Venegas, and H. Choren, 2005: Analysis of $\mathrm{NO}, \mathrm{NO}_{2}, \mathrm{O}_{3}$ and $\mathrm{NO}_{\mathrm{X}}$ concentrations measured at a green area of Buenos Aires City during wintertime.Atmos. Environ., 39, 3055-3068.

Park, S. U., and Y. H. Lee, 2002: Spatial distribution of wet deposition of nitrogen in South Korea. Atmos. Environ., 36, 619-628.

Shahgedanova, M., T. P. Burt, and T. D. Davies, 1999: Carbon monoxide an nitrogen oxides pollution in Moscow. Water, Air, Soil Poll., 112, 107-131.

Silibello, C., G. Carlori, G. Brusasca, G. Catenacci, and G. Finzi, G., 1998: Application of a photochemical grid model to Milan metropolitan area.Atmos. Environ., 32, 2025-2038.

Soltic, P., and M. Weilenmann, 2003: $\mathrm{NO}_{2} / \mathrm{NO}$ emissions of gasoline passenger cars and light-duty trucks with Euro-2 emission standard. Atmos. Environ., 37, 5207-5216.

Stedman, J. R., W. L. Justin, K. Goodwin, T. P. Murrells, and T. J. Bush, 2001: An empirical model for predicting urban roadside nitrogen dioxide concentrations in the UK. Atmos. Environ., 35, 1451-1463. 